\title{
ANALISIS MUTU KIMIA CASCARA YANG DIPEROLEH DARI KOMBINASI WAKTU DAN SUHU PENGERINGAN SERTA PENGECILAN UKURAN YANG BERBEDA
}

\author{
Murna Muzaifa $^{1)}$, Yusriana ${ }^{1)}$, M. Shabir Azmi ${ }^{1)}$, dan Faidha Rahmi ${ }^{2)}$ \\ ${ }^{1}$ Jurusan Teknologi Hasil Pertanian, Fakultas Pertanian Universitas Syiah Kuala Darussalam Banda Aceh 23111 \\ ${ }^{2}$ Jurusan Agroteknologi, Fakultas Pertanian, Universitas Gadjah Putih, Aceh Tengah 24552 \\ Email: murnamuzaifa@unsyiah.ac.id
}

\begin{abstract}
ABSTRAK
Telah dilakukan penelitian untuk menganalisis mutu kimia seduhan cascara yang diperoleh dari kombinsi suhu dan waktu pengeringan. Penelitian ini merupakan penelitian eksperimental menggunakan RAK (Rancangan Acak Kelompok) faktorial menggunakan 2 faktor. Faktor pertama adalah kombinasi suhu dan waktu pengeringan (T) terdiri dari 2 taraf yaitu pengeringan tray dryer suhu $37{ }^{\circ} \mathrm{C}$ selama 20 jam (T1) dan pengeringan tray dryer suhu $45{ }^{\circ} \mathrm{C}$ selama 10 jam (T2). Faktor kedua adalah pengecilan ukuran teh cascara $(\mathrm{P})$ terdiri dari 2 taraf yaitu pengecilan ukuran 20 mesh (P1), dan tanpa pengecilan ukuran teh cascara (P2). Dengan demikian dihasilkan 4 kombinasi perlakuan dengan pengulangan sebanyak 3 kali sehingga diperoleh total 12 unit percobaan. Parameter seduhan teh cascara yang diamati adalah nilai $\mathrm{pH}$, total padatan terlarut, total fenol dan aktivitas antioksidan. Hasil penelitian menunjukkan bahwa kombinasi suhu dan waktu pengeringan mempengaruhi total fenol dan aktivitas antioksidan seduhan cascara. Kombinasi suhu pengeringan $37^{\circ} \mathrm{C}$ dengan waktu selama 20 jam menghasilkan total fenol dan aktivitas antioksidan yang lebih tinggi dibandingkan dengan kombinasi suhu pengeringan $45^{\circ} \mathrm{C}$ selama 10 jam. proses pengecilan ukuran mempengaruhi nilai $\mathrm{pH}$ nilai dan total padatan terlarut seduhan cascara. Dengan melakukan pengecilan ukuran komponen kimia yang terekstrak menjadi lebih besar sehingga keasaman dan total padatan terlarut semakin meningkat.

Kata kunci: arabika gayo; cascara; fermentasi; pulp; seduhan
\end{abstract}

\section{PENDAHULUAN}

Kopi merupakan minuman penting bagi sebagian besar masyarakat dunia. Dengan kenikmatan citarasa dan nilai ekonomisnya menjadikan kopi sebagai salah satu komoditas yang paling banyak diperdagangkan. Indonesia merupakan salah satu negara produsen kopi dunia dengan luas perkebunannya mencapai 1,25 juta ha. Perkebunan kopi di Indonesia didominasi oleh jenis kopi robusta dengan total produksi mencapai 80\% (Mc Donald, 2019).

Bagian yang paling bernilai dari buah kopi adalah bijinya. Dalam proses pengambilan biji ini akan dihasilkan sejumlah produk samping berupa kulit buah merah (pulp), kulit tanduk, mucilage atapun kulit ari (Belitz et al., 2009; Esquivel and Jiménez, 2012; Mussatto et al., 2011). Hasil samping ini dapat mencapai 40-60\% dari hasil panen dan pulp paling banyak dihasilkan dibandingkan produk samping lainnya. Pulp diketahui mengandung sejumlah komponen kimia penting seperti karbohidrat, protein, lemak, mineral, serat, serta sejumlah senyawa polifenol penting seperti asam klorogenat, antosianidin, flavonol, katekin, rutin dan, tanin dan asam ferulat (Esquivel and Jiménez, 2012; Pandey et al., 2000).

Permasalahan penanganan produk samping adalah permasalahan umum yang dihadapi oleh negara berkembang produsen kopi termasuk Indonesia. Sejauh ini pemanfaatan pulp di Indonesia masih terbatas. Pemanfaatan pulp kopi untuk minuman teh sudah mulai dikenal namun sejauh ini belum popular di masyarakat. Berbeda dengan di Swiss, negara bukan produsen kopi namun memiliki sejumlah pabrik minuman berbasis cascara. Kualitas teh cascara dapat dipengaruhi oleh banyak faktor, diantaranya jenis bahan baku serta varietas kopi yang digunakan (Heeger et al., 2017). Sembiring et al., (2015) mengatakan hal tersebut juga dipengaruhi oleh proses pengolahan basah atau kering terhadap pulp kopi. Menurut Limbong (2019), perbedaan lama variasi seduhan juga akan berpengaruh terhadap kualitas teh cascara yang dihasilkan. Selain dari berbagai faktor tersebut, metode pengeringan yang akan dilakukan pada cascara berpotensi mempengaruhi teh cascara.

Cascara biasa dijual dalam bentuk utuh dan diperoleh langsung dari perkebunan petani yang dijemur dengan sinar matahari, hal ini belum sepenuhnya dapat diterima masyarakat. Kesan kulit kopi 
sebagai hasil samping (limbah) dapat mempengaruhi persepsi konsumen. Pengeringan menggunakan alat menjadi alternatif dalam pengeringan cascara. Menurut Thamkaew et al., (2020) pengeringan dengan menggunakan sinar matahari memiliki beberapa kekurangan selain kurang higenis, juga membutuhkan waktu yang lama serta sangat bergantung kepada cuaca. Pengeringan dengan menggunakan alat seperti tray dryer selain dapat menghemat waktu juga dapat menjaga kualitas dan kebersihan produk cascara. Upaya pengembangan minuman cascara sebagai minuman komersial perlu dioptimalkan. Produksi cascara dalam bentuk bubuk diduga dapat meningkatkan penerimaannya. Penelitian ini bertujuan untuk mengetahui pengaruh kombinasi metode dan waktu pengeringan serta pengecilan ukuran terhadap mutu kimia teh cascara.

\section{METODOLOGI PENELITIAN}

\section{A. Bahan dan Peralatan}

Bahan baku utama yang digunakan pada penelitian ini adalah pulp buah kopi arabika (berwarna merah ceri) yang diperoleh dari kabupaten Aceh Tengah. Bahan uji kimia yang digunakan pada penelitian ini yaitu akuades, reagen follin ciocalteu, $\mathrm{Na}_{2} \mathrm{CO}_{3} 5 \%$ serta etanol $95 \%$. Peralatan yang digunakan pada penelitian ini adalah tray dryer, penumbuk, ember, pulper, blender, siever, $\mathrm{pH}$ meter, timbangan analitik, stoples kaca, saringan, tabung reaksi, waterbath, kuvet, kompor gas, labu erlemenyer, gelas piala, pipet tetes, refractometer, spektrofotometer-UV

\section{B. Rancangan Penelitian}

Penelitian ini merupakan penelitian eksperimental menggunakan RAK (Rancangan Acak Kelompok) faktorial menggunakan 2 faktor. Faktor pertama adalah kombinasi suhu dan waktu pengeringan (T) terdiri dari 2 taraf yaitu pengeringan tray dryer suhu $37{ }^{\circ} \mathrm{C}$ selama 20 jam (T1) dan pengeringan tray dryer suhu $45{ }^{\circ} \mathrm{C}$ selama 10 jam (T2). Faktor kedua adalah pengecilan ukuran teh cascara $(\mathrm{P})$ terdiri dari 2 taraf yaitu pengecilan ukuran 20 mesh (P1), dan tanpa pengecililan ukuran teh cascara (P2). Dengan demikian menghasilkan 4 kombinasi dengan pengulangan sebanyak 3 kali maka diperoleh 12 satuan percobaan sebagaimana terlihat pada Tabel 1.

Tabel 1. Susunan Rancangan Percobaan dengan Kombinasi Suhu dan Waktu Pengeringan Serta Pengecilan Ukuran

\begin{tabular}{lllll}
\hline $\begin{array}{l}\text { Kombinasi suhu dan waktu } \\
\text { pengeringan }(\mathrm{T})\end{array}$ & Pengecilan Ukuran $(\mathrm{P})$ & Ulangan & & \\
\hline T1 (pengeringan dengan & P1 (Pengecilan ukuran 20 mesh) & T1P1U1 & T1P1U2 & T1P1U3 \\
suhu 37 ${ }^{\circ}$ C selama 20 jam) & P2 (Tanpa pengeciln ukuran)) & T1P2U1 & T1P2U2 & T1P2U3 \\
T2 (pengeringan dengan & P1 (Pengecilan ukuran 20 mesh) & T2P1U1 & T2P1U2 & T2P1U3 \\
suhu 45 ${ }^{\circ}$ C selama 10 jam) & P2 (Tanpa pengecilan ukuran) & T2P2U1 & T2P2U2 & T2P2U3 \\
\hline
\end{tabular}

\section{Prosedur Penelitian}

1. Persiapan Bahan Baku

Buah kopi segar yang baru dipanen diperoleh dari petani kopi di Kabupaten Aceh Tengah. Buah kopi diperoleh dari hasil panen petani disortasi dengan cara manual yang bertujuan untuk memisahkan buah muda dan benda asing lainnya. Selanjutnya dilakukan penggilingan buah kopi dengan mesin pulper yang bertujuan untuk memisahkan biji kopi dan kulit buah (pulp).

\section{Pembuatan Cascara}

Proses pembuatan cascara merujuk pada prosedur Umanzor (2017). Ditimbang pulp yang sudah dikumpulkan untuk masing-masing perlakuan sebesar 500g. Pulp yang diperoleh selanjutnya diperlakukan sesuai dengan rancangan percobaan (Tabel 1) yaitu dengan mengkombinasikan suhu dan waktu pengeringan pulp pada alat tray dryer, pengeringan dengan suhu $37{ }^{\circ} \mathrm{C}$ selama 20 jam(T1) dan pengeringan dengan suhu $45{ }^{\circ} \mathrm{C}$ selama 10 jam (T2). Cascara yang dihasilkan pada pengeringan tersebut selanjutnya ditimbang masing-masing sebanyak 250 gram untuk diberikan proses perlakuan berbeda yaitu dengan pengecilan ukuran 20 mesh (P1) dan tanpa pengecilan ukuran (P2). Cascara yang dihasilkan selanjutnya diseduh untuk dianalisis. 


\section{Penyeduhan Cascara}

Penyeduhan mengikuti prosedur Heeger et al., (2017) dengan sedikit modifikasi. Cascara yang diperoleh dari masing-masing perlakuan ditimbang sebanyak 3 gram, ditambahkan air panas bersuhu $90^{\circ} \mathrm{C}$. Penyeduhan dilakukan selama 6 menit 30 detik. Cascara disaring, hasil seduahnnya siap dianalisis.

\section{Analisis Kimia dan Sensori Seduhan Cascara}

Parameter yang dianalisis adalah komponen kimia dari seduhan cascara meliputi nilai $\mathrm{pH}$, total padatan terlarut, total fenol serta aktivitas antioksidan. Analisis $\mathrm{pH}$ dilakukan dengan menggunakan pH meter sedangkan total padatan terlarut menggunakan refraktometer (Sudarmadji, 1997). Analisis fenol menggunakan Folin- Ciocalteau (Sakanaka et al., 2005) dan analisis aktivitas antioksidan dilakukan dengan metode 2,2-diphenyl-1-picrylhydrazyl (DPPH) (Sompong et al., 2011).

\section{Analisis Data}

Data hasil penelitian dianalisis secara statistik dengan Anova. Uji lanjut yang digunakan adalah Duncan Multiple Range Test (DMRT) pada taraf 0,05.

\section{HASIL DAN PEMBAHASAN}

\section{A. Nilai pH Seduhan Cascara}

Proses penyeduhan teh cascara dilakukan dengan menggunakan air bersuhu $90^{\circ} \mathrm{C}$ dengan lama penyeduhan 6 menit 30 detik (Heeger et al., 2017). Nilai pH seduhan cascara yang dihasilkan berkisar antara 4,71-4,94 dengan rerata 4,84. Hasil analisis ragam menunjukkan bahwa kombinasi suhu dan waktu pengeringan (T), kombinasi suhu dan waktu serta pengecilan ukuran (TP) tidak berpengaruh secara nyata $(p>0,05)$ terhadap nilai $\mathrm{pH}$. Pengecilan ukuran $(\mathrm{P})$ berpengaruh sangat nyata $(\mathrm{p} \leq 0,01)$ terhadap nilai $\mathrm{pH}$. Pengaruh pengecilan ukuran terhadap nilai $\mathrm{pH}$ teh cascara dapat dilihat pada Gambar 1.

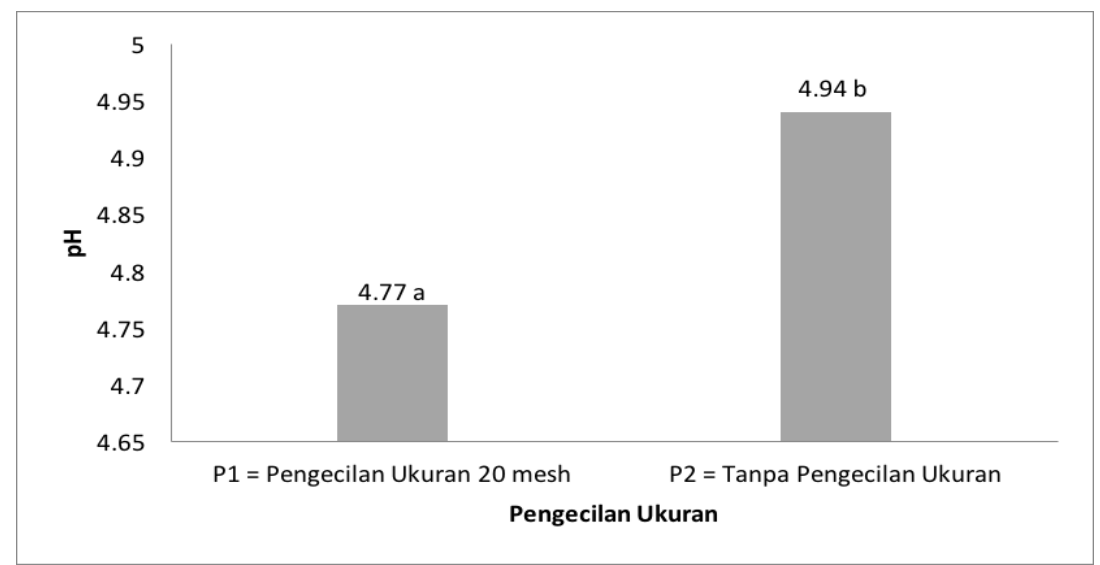

Gambar 1. Pengaruh Pengecilan Ukuran (P) terhadap Nilai $\mathrm{pH}$

(nilai dengan huruf berbeda menunjukkan perbedaan nyata pada uji $\mathrm{DMRT}_{0,05}$ )

Gambar 1 menunjukkan bahwa nilai pH dengan pengecilan ukuran 20 mesh (P1) sebesar 4,77 lebih rendah dibandingkan dengan tanpa pengecilan ukuran (P2) yaitu 4,94. Hal ini disebabkan karena pengecilan ukuran mempengaruhi luas permukaan pada teh cascara. Dengan luas permukaan teh cascara yang lebih besar ekstraksi komponen kimia seperti asam organik menjadi lebih banyak sehingga $\mathrm{pH}$ menjadi lebih rendah. $\mathrm{pH}$ yang rendah dinginkan pada cascara karena memberikan sensasi rasa asam segar dengan kombinasi manis yang sudah dimiliki oleh cascara. Menurut Andueza et al., (2002), proses ektraksi bergantung seberapa luas permukaan bahan tersebut yang akan terpapar dengan medium pelarut. Semakin besar luas permukaan dari bahan, maka dapat memaksimalkan kandungan yang ada. Menurut Rahardian (2013) sama halnya dengan tujuan pada proses penggilingan pada teh hitam yaitu agar cairan sel keluar semaksimal mungkin sehingga terjadi kontak dengan oksigen, enzim dan substrat sehingga terjadi proses oksidasi enzimatis. 


\section{B. Total Padatan Terlarut Seduhan Cascara}

Nilai total padatan terlarut seduhan teh cascara dari penelitian ini berkisar antara 0,20$0,37^{\circ}$ Brix dengan rerata $0,28^{\circ}$ Brix. Hasil analisis ragam menunjukkan bahwa pengecilan ukuran $(\mathrm{P})$ berpengaruh nyata $(\mathrm{p} \leq 0,01)$ terhadap total padatan terlarut. Pengaruh pengecilan ukuran terhadap nilai total padatan terlarut teh cascara dapat dilihat pada Gambar 2.

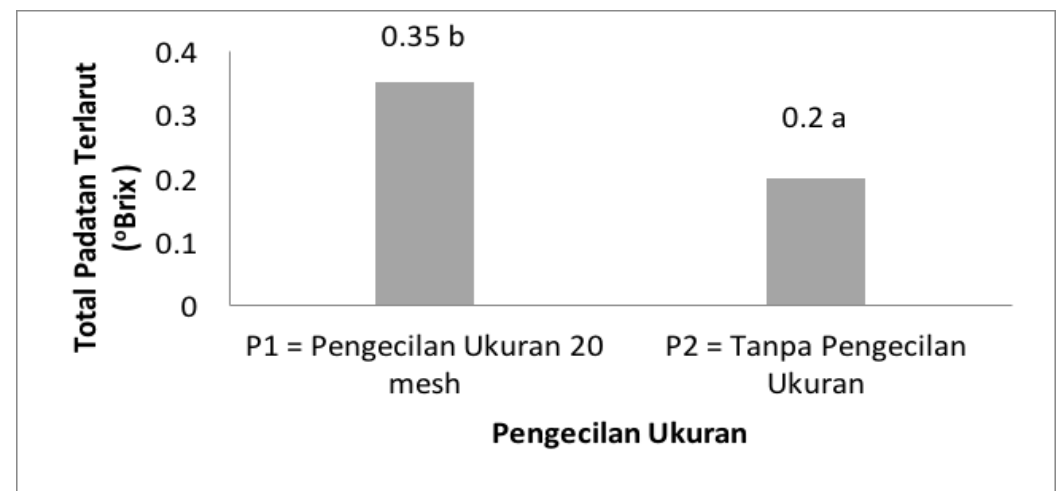

Gambar 2. Pengecilan Ukuran (P) terhadap Nilai Total Padatan Terlarut (nilai dengan huruf berbeda menunjukkan perbedaan nyata pada uji $\mathrm{DMRT}_{0,05}$ )

Total padatan terlarut yang lebih besar diperoleh pada pengecilan ukuran 20 mesh (P1) sebesar $0,35^{\circ}$ Brix sedangkan tanpa pengecilan ukuran (P2) lebih rendah yaitu $0,2^{\circ}$ Brix. Hal ini dikarenakan pengecilan ukuran menyebabkan luas permukaan bahan semakin besar, sehingga dapat memaksimalkan proses terekstraknya seduhan teh cascara. Murray dan Laredo (2014) menyatakan partikel dengan ukuran kecil memberikan peluang yang lebih besar (karena luas permukaan yang semakin besar) untuk kontak langsung dengan air. Hal ini sesuai dengan hasil penelitian Tambun et al., (2016) dan Yadav et al., (2018), semakin kecil ukuran partikel maka luas permukaan zat akan semakin meningkat dan semakin banyak pori-pori yang terbentuk sehingga mempercepat kelarutan suatu zat dan memberikan pengaruh yang lebih signifikan terhadap hasil ekstraksi.

\section{Total Fenol Seduhan Cascara}

Analisis total fenol dilakukan dengan mengguakan metode Follin-Ciocalteau. Metode ini dilakukan dengan menggunakan alat UV-Vis Spektrofotometer agar membaca ukuran senyawa fenolik yang terdapat pada seduhan teh cascara serta penggunaan larutan asam galat sebagai standartnya. Nilai total fenol seduhan teh cascara berkisar antara 25,16-30,37 mg GAE/ml dengan rerata $27,41 \mathrm{mg} \mathrm{GAE} / \mathrm{ml}$. Hasil analisis ragam menunjukkan bahwa pengecilan ukuran $(\mathrm{P})$ dan interaksi kombinasi suhu dan waktu pengeringan serta pengecilan ukuran (PT) tidak berpengaruh nyata $(p>0,05)$ terhadap analisis total fenol. Sedangkan kombinasi suhu dan waktu pengeringan $(T)$ berpengaruh nyata $(\mathrm{p} \leq 0,05)$ terhadap analisis total fenol. Pengaruh kombinasi suhu dan waktu pengeringan terhadap total fenol dapat dilihat pada Gambar 3.

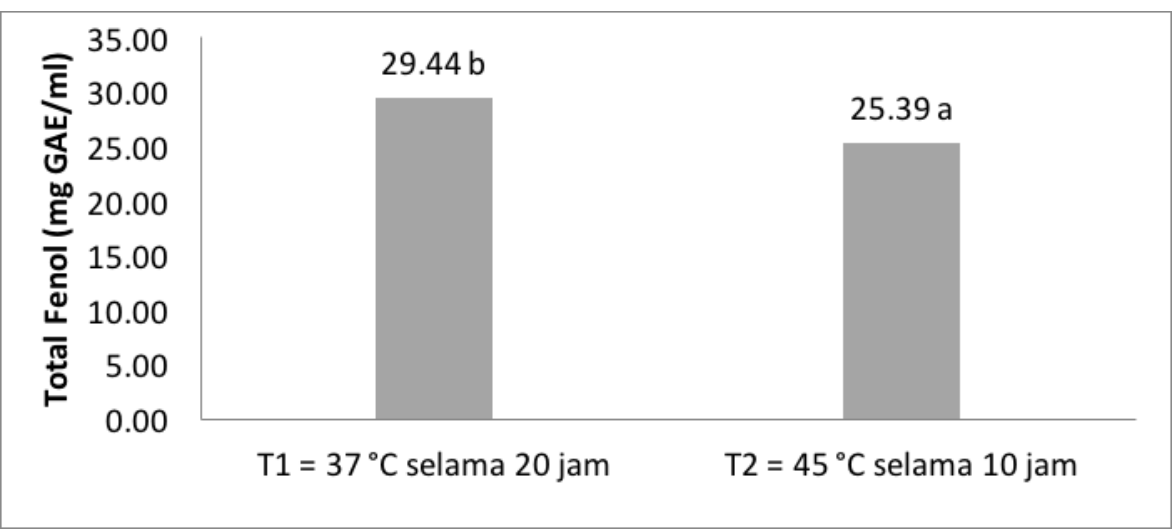

Gambar 3. Kombinasi Suhu dan Waktu Pengeringan (T) terhadap Nilai Fenol (nilai berbeda menunjukkan perbedaan nyata pada uji $\mathrm{DMRT}_{0,05}$ ) 
Hasil uji DMRT ${ }_{0,05}$ menunjukkan nilai total fenol yang diperoleh pada kombinasi suhu pengeringan $37^{\circ} \mathrm{C}$ selama 20 jam (T1) yaitu $29,44 \mathrm{mg}$ GAE/ml lebih tinggi dibandingkan dengan kombinasi suhu pengeringan $45^{\circ} \mathrm{C}$ selama 10 jam (T2) yaitu 25,39 mg GAE/ml. Diduga senyawa fenol lebih sensitif terhadap kondisi panas, suhu yang tinggi dapat menurunkan senyawa fenol. Liyana-Pathirana dan Shahidi (2005) menyebutkan adanya keterkaitan antara suhu dan senyawa fenolik, senyawa fenolik akan cenderung menurun dengan peningkatan suhu yang lebih tinggi akibat terjadinya dekomposisi senyawa fenolik. Hasil penelitian Purbowati et al., (2016) menunjukkan bahwa ekstrak kelopak bunga rosella akan mengalami penurunan kandungan total fenolik untuk setiap kenaikan satu satuan suhu dan lama waktu pemanasan.

\section{Aktivitas Antioksidan}

Nilai aktivitas antioksidan yang diperoleh pada penelitian ini berkisar antara 62,06-80,48\% dengan rerata $71,11 \%$. Hasil sidik ragam menunjukkan bahwa pengecilan ukuran dan interaksi kombinasi suhu dan waktu pengeringan serta pengecilan ukuran tidak berpengaruh nyata $(\mathrm{p}>0,05)$ terhadap aktivitas antioksidan. Kombinasi suhu dan waktu pengeringan berpengaruh nyata $(\mathrm{p} \leq 0.01)$ terhadap aktivitas antioksidan pada teh cascara. Pengaruh kombinasi suhu dan waktu pengeringan terhadap nilai aktivitas antioksidan dapat dilihat pada Gambar 4.

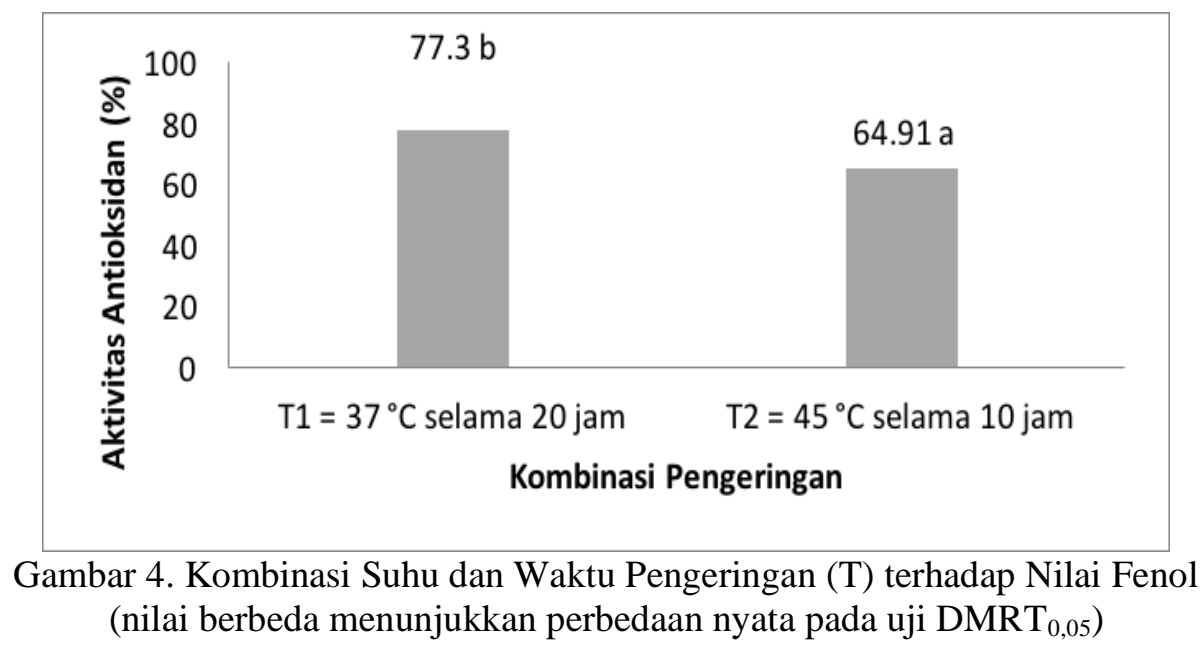

Hasil uji DMRT 0,05 menunjukkan bahwa nilai aktivitas antioksidan pada kombinasi suhu pengeringan $37^{\circ} \mathrm{C}$ selama 20 jam (T1) yaitu sebesar $77,3 \%$ lebih tinggi dibandingkan dengan kombinasi suhu pengeringan $45^{\circ} \mathrm{C}$ selama 10 jam (T2) yaitu 64,76\%. Hal ini diduga disebabkan karena rusaknya senyawa yang berkontribusi terhadap aktivitas antioksidan pada suhu yang lebih tinggi dalam hal ini adalah senyawa fenol. Xu dan Howard (2012) menyebutkan senyawa fenol merupakan salah satu senyawa yang dapat dikategorikan sebagai senyawa antioksidan. Senyawa fenol mampu mereduksi senyawa radikal bebas dengan mendonorkan atom hidrogennya kepada oksigen singlet dan kemudian fenol akan teroksidasi menjadi radikal fenoksi yang stabil. Radikal fenoksi merupakan senyawa yang relatif stabil karena akan terjadi resonansi pada cincin fenolik, sehingga radikal tersebut tidak membentuk radikal bebas baru melainkan bereaksi dengan radikal bebas lain untuk menghentikan reaksi berantai.

Jacobo-Velázquez dan Cisneros-Zevallos (2009) menyatakan bahwa senyawa fenolik merupakan bagian dari komponen aktivitas antioksidan dalam bahan pangan yang rentan akan suhu tinggi. Hal ini sejalan dengan (Simanjuntak Noviar; Efendi, Raswen (2014) dan Permata (2015) yang menyebutkan bahwa beberapa senyawa antioksidan rusak pada suhu yang terlalu tinggi. Hasil penelitian Nafisah and Widyaningsih (2018) menunjukkan bahwa nilai aktivitas antioksidan pada seduhan teh cascara dengan metode pengeringan oven menggunakan suhu $60^{\circ} \mathrm{C}$ selama 5 jam lebih rendah dibandingkan dengan metode pengeringan konvensional dengan penjemuran dibawah sinar matahari selama 20 jam. Dengan demikian kenaikan suhu lebih peka pengaruhnya terhadap kandungan antioksidan bahan pangan dalam hal ini adalah senyawa fenol. 


\section{KESIMPULAN DAN SARAN}

\section{A. Kesimpulan}

Kombinasi suhu dan waktu pengeringan tidak mempengaruhi nilai $\mathrm{pH}$ cascara, namun berpengaruh terhadap total fenol dan aktivitas antioksidan cascara yang dihasilkan. Kombinasi suhu pengeringan $37^{\circ} \mathrm{C}$ dengan waktu selama 20 jam menghasilkan total fenol dan aktivitas antioksidan yang lebih tinggi dibandingkan dengan kombinasi suhu pengeringan $45^{\circ} \mathrm{C}$ selama 10 jam. Pengecilan ukuran cascara mempengaruhi nilai $\mathrm{pH}$ dan total padatan terlarut seduhan cascara, pengecilan ukuran akan mengekstrak komponen kimia yang lebih besar sehingga keasaman dan total padatan terlarut semakin meningkat.

\section{B. Saran}

Perlu dilakukan penelitian lanjut terhadap komponen kimia penting lainnya yang berperan terhadap pembentukan citarasa cascara antara lain komponen asam organik dan senyawa volatil serta korelasinya dengan citarasa cascara yang dihasilkan.

\section{DAFTAR PUSTAKA}

Andueza, S., Maeztu, L., Dean, B., De Peña, M.P., Bello, J., Cid, C., 2002. Influence of Water Pressure on the Final Quality of Arabica Espresso Coffee. Application of Multivariate Analysis. J. Agric. Food Chem. doi:10.1021/jf0206623

Belitz, H.D., Grosch, W., Schieberle, P., 2009. Food Chemistry, Food Chemistry. doi:10.1007/978-3540-69934-7

Esquivel, P., Jiménez, V.M., 2012. Functional Properties of Coffee and Coffee by-Products. Food Res. Int. doi:10.1016/j.foodres.2011.05.028

Heeger, A., Kosińska-Cagnazzo, A., Cantergiani, E., Andlauer, W., 2017. Bioactives of Coffee Cherry Pulp and its Utilisation for Production of Cascara Beverage. Food Chem. doi:10.1016/j.foodchem.2016.11.067

Jacobo-Velázquez, D.A., Cisneros-Zevallos, L., 2009. Correlations of Antioxidant activity Against Phenolic Content Revisited: A new Approach in Data Analysis for Food and Medicinal Plants. J. Food Sci. doi:10.1111/j.1750-3841.2009.01352.x

Limbong, M. S.P. 2019. Pengaruh Perlakuan Pulp Kopi dan Lama Seduhan terhadap Mutu Cascara dan Seduhannya. Skripsi. Universitas Syiah Kuala

Liyana-Pathirana, C., Shahidi, F., 2005. Optimization of Extraction of Phenolic Compounds from Wheat Using Response Surface Methodology. Food Chem. doi:10.1016/j.foodchem.2004.08.050

Mc Donald, G. 2019. Indonesia Coffee Annual Report 2019. USDA Foreign Agricultural Service https://apps.fas.usda.gov/newgainapi/api/report diakses 22 Februari 2020.

Murray, C., Laredo, T., 2014. Effect of Home Grinding on Properties of Brewed Coffee. J. Food Res. doi:10.5539/jfr.v4n1p77

Mussatto, S.I., Machado, E.M.S., Martins, S., Teixeira, J.A., 2011. Production, Composition, and Application of Coffee and Its Industrial Residues. Food Bioprocess Technol. doi:10.1007/s11947-011-0565-z

Nafisah, D., Widyaningsih, T.D., 2018. Kajian Metode Pengeringan dan Rasio Penyeduhan pada Proses Pembuatan Teh Cascara Kopi Arabika ( Coffea arabica L .) Study of Drying Method and Brewing Ratio in Process of Making Cascara Tea from Arabica Coffee (Coffea arabika L .). Pangan dan Agroindustri 6, 37-47.

Pandey, A., Soccol, C.R., Nigam, P., Brand, D., Mohan, R., Roussos, S., 2000. Biotechnological Potential of Coffee Pulp and Coffee Husk for Bioprocesses. Biochem. Eng. J. doi:10.1016/S1369-703X(00)00084-X

Permata, D. 2015. Aktivitas Inhibisi Amilase dan Total Polifenol Teh Daun Sisik Naga Pada Suhu dan Pengeringan yang Berbeda. Seminar Agroindustri dan Lokakarya Nasional FKPT-TPI, 2-3 September 2015. Universitas Andalas.

Purbowati, I.S.M., Syamsu, K., Warsiki, E., Sri, H., 2016. Stabilitas Senyawa Fenolik dalam Ekstrak dan Nanokapsul Kelopak Bunga Rosella pada Berbagai Variasi pH, Suhu dan Waktu. Agrointek. doi:10.21107/agrointek.v10i1.2023 


$=================================================================$
Purnomo. S, 2018. Produk Olahan Limbah Kopi. Jawa pos. URL
https://www.jawapos.com/features/09/07/2018/60-kg-kopi-hasilkan-1-kg-teh/

Rahardian, D. 2013. Teknologi Pengolahan Teh Hitam. Jurusan Ilmu Dan Teknologi Pangan Universitas Sebelas Maret. Surakarta.

Sakanaka, S., Tachibana, Y., Okada, Y., 2005. Preparation and Antioxidant Properties of Extracts of Japanese Persimmon Leaf Tea (kakinoha-cha). Food Chem. doi:10.1016/j.foodchem.2004.03.013

Sembiring, N., Satriawan, I., Tuningrat, I., 2015. Nilai Tambah Proses Pengolahan Kopi Arabika Secara Basah (West Indischee Bereding) dan Kering (Ost Indischee Bereding) Di Kecamatan Kintamani, Bangli. J. Rekayasa Dan Manaj. Agroindustri 3, 61-72.

Simanjuntak Noviar; Efendi, Raswen, L.H., 2014. Penerimaan Panelis Terhadap Teh Herbal dari Kulit Buah Manggis (Garcinia mangostana L.) dengan Perlakuan Suhu Pengeringan. J. Online Mhs. Bid. Pertan.

Sompong, R., Siebenhandl-Ehn, S., Linsberger-Martin, G., Berghofer, E., 2011. Physicochemical and Antioxidative Properties of Red and Black Rice Varieties from Thailand, China and Sri Lanka. Food Chem. doi:10.1016/j.foodchem.2010.05.115

Sudarmadji, S. 1997. Prosedur Analisa untuk Bahan Makanan dan Pertanian. Liberty, Jakarta.

Tambun, R., Limbong, H.P., Pinem, C., Manurung, E., 2016. Pengaruh Ukuran Partikel, Waktu dan Suhu pada Ekstraksi Fenol dari Lengkuas Merah. J. Tek. Kim. USU.

Thamkaew, G., Sjöholm, I., Galindo, F.G., 2020. A Review of Drying Methods for Improving the Quality of Dried Herbs. Crit. Rev. Food Sci. Nutr. doi:10.1080/10408398.2020.1765309

Umanzor, C. 2017. Sensory Characterization and Analysis of Tea Infusions from Dry Coffee Cheery Pulp "Cascara" from Washed and Natural Processed Coffee. Thesis. Universitas Studiorom Utinensis, Honduras.

Xu, Z., Howard, L.R., 2012. Analysis of Antioxidant-Rich Phytochemicals, Analysis of AntioxidantRich Phytochemicals. doi:10.1002/9781118229378

Yadav, G.U., Farakte, R.A., Patwardhan, A.W., Singh, G., 2018. Effect of Brewing Temperature, Tea Types and Particle Size on Infusion of Tea Components. Int. Food Res. J. 